Highlights of Astronomy, Vol. 13

International Astronomical Union, 2003

O. Engvold, ed.

\title{
A Contemporary Review of K-16 Astronomy Education Research
}

\author{
Janelle M. Bailey \& Timothy F. Slater \\ Conceptual Astronomy and Physics Education Research (CAPER) Team \\ Dept. of Astronomy, Univ. of Arizona, Tucson, AZ, 85721 USA \\ E-mail: jbailey@as.arizona.edu, tslater@as.arizona.edu
}

Astronomy education research (AER) uses the systematic techniques honed in science education and physics education research to understand what and how students learn about astronomy, and determine how instructors can create more productive learning environments for their students. A recent review of the literature in this area revealed a number of articles that could be classified into four major categories: research into student understanding, research on instructional methods, research on teacher understanding, and descriptions of curriculum materials.

Within the area of student understanding research, a number of topics have been investigated. The most extensive area that has been researched thus far is the shape of Earth (and its relation to gravity). Studies on this topic have included children in grades two through eight and in the United States, Nepal, Israel and the United Kingdom. Investigations into understanding of lunar phases have included students in elementary grades and university, as well as pre-service teachers, all in the U.S. Understanding of seasons is studied for university students and teachers in the U.S., while understanding diurnal motion (the day/night cycle) includes those populations plus elementary students. Investigations in astrobiology and cosmology have begun with U.S. secondary and university students. The Astronomy Diagnostic Test (ADT) has been developed and administered to university students across the U.S.

As an example of the research literature review, we will elaborate on the shape of Earth research. In 1976, Nussbaum and Novak interviewed second grade students about Earth's shape. Although many students initially responded with the answer "round," deeper probing revealed that "round" does not always mean "round like a ball." The researchers found five different notions that represent the students' mental models of Earth's shape. These results were similarly found using multiple-choice instruments with Israeli students in several grades (Nussbaum 1979) as well as in Nepali students (Mali \& Howe 1979). Klein (1982) and Sneider \& Pulos (1983) further expanded these results across grade levels and student populations. Targeted instructional methods were investigated by Nussbaum \& Sharoni-Dagan (1983). Investigations by Jones, Lynch \& Reesink (1987) and Baxter (1989) confirmed similar results. Vosniadou \& Brewer (1992) expanded the classification criteria and mental models in their investigations.

Students' understanding of lunar phases and of seasons was first made public by the video A Private Universe (Schneps 1989). Studies by Stahly, Krockover \& Shepardson (1999), Lindell (2001), and Trundle, Atwood \& Christopher (2002) demonstrate that the most common misconception about the cause of the lunar phases is what is commonly called the "eclipse model." In this model, students 
believe the phases are caused by the Moon moving in and out of Earth's shadow, allowing some portion of the sunlight to be blocked. Fanetti (2001) believes this can be traced to a poor understanding of size and scale.

Instruction method investigations include personalized system of instruction (Zeilik 1974), collaborative group learning (e.g., Adams \& Slater 2002), conceptual-based courses (Zeilik et al. 1997; Zeilik, Schau \& Mattern 1999), and the use of planetarium instruction (e.g., Reed \& Campbell 1972).

Callison \& Wright (1993) studied the effectiveness of using three-dimensional models to instruct on lunar phases, while Barnett \& Morran (2002) studied project-based instruction. Several of the previously described studies on student understanding of lunar phases included instructional aspects (Lindell 2001; Stahly, Krockover \& Shepardson 1999; Trundle, Atwood \& Christopher 2002). Abell and colleagues describe the effectiveness of using observation projects to help pre-service teachers understand lunar phases (Abell, George \& Martini 2001; Abell, Martini \& George 2002).

Several of the studies described above use pre-service and/or in-service teachers as their study population. Barba \& Rubba (1992) investigated the differences in knowledge levels between in-service ("expert") and preservice ("novice") teachers. Slater (1993) examined the effectiveness of constructivist strategies in teacher professional development in astronomy.

A large number of articles describing specific curriculum materials or activities can be found throughout the literature. A summary of these pieces is beyond the scope of this work; however, an extensive bibliography of such activities can be found at the Astronomical Society of the Pacific's education website.

To date, few astronomy concepts have been investigated in any depth; consider in comparison the extensive literature base in physics education research. Furthermore, few instructional strategies and curriculum materials have been rigorously examined for their effectiveness in helping students learn astronomical concepts. Future efforts should focus on expanding these areas in terms of both topics and student populations, as well as developing effective strategies to prepare astronomy teachers.

\section{References}

Abell, S., George, M. \& Martini, M. 2001, "The Moon investigation: Instructional strategies for elementary science methods," Journal of Science Teacher Education, $13(2), 85$

Abell, S., Martini, M. \& George, M. 2002, "'That's what scientists have to do': Preservice elementary teachers' conceptions of the nature of science during a Moon investigation," International Journal of Science Education, 23(11), 1095

Adams, J. P. \& Slater, T. F. 2002, "Learning through sharing: Supplementing the astronomy lecture with collaborative-learning group activities," Journal of College Science Teaching, 31, 384

Barba, R. \& Rubba, P. A. 1992, "A comparison of preservice and in-service earth and space science teachers' general mental abilities, content knowledge, and problemsolving skills," Journal of Research in Science Teaching, 29, 1021

Barnett, M. \& Morran, J. 2002, "Addressing children's alternative frameworks of the Moon's phases and eclipses," International Journal of Science Education, 24(8), 859 
Baxter, J. 1989, "Children's understanding of familiar astronomical events," International Journal of Science Education, 11, 502

Callison, P. L. \& Wright, E. L. 1993, April, "The effect of teaching strategies using models on preservice elementary teachers' conceptions about Earth-Sun-Moon relationships", Paper presented at the Annual Meeting of the National Association for Research in Science Teaching, Atlanta, GA

Fanetti, T. M. 2001, "The relationships of scale concepts on college age students' misconceptions about the cause of lunar phases", Unpublished master's thesis, Iowa State University, Ames

Jones, B. L., Lynch, P. P. \& Reesink, C. 1987, "Children's conceptions of the Earth, Sun and Moon," International Journal of Science Education, 9, 43

Klein, C. 1982, "Children's concepts of the Earth and the Sun: A cross-cultural study," Science Education, 65, 95

Lindell, R. S. 2001, "Enhancing college students' understanding of lunar phases", Unpublished doctoral dissertation, University of Nebraska, Lincoln

Mali, G. \& Howe, A. 1979, "A development of Earth and gravity concepts among Nepali children," Science Education, 63, 685

Nussbaum, J. 1979, "Children's conception of the Earth as a cosmic body: A cross age study," Science Education, 63, 83

Nussbaum, J. \& Novak, J. 1976, "An assessment of children's concepts of the Earth utilizing structured interviews," Science Education, 60, 535

Nussbaum, J. \& Sharoni-Dagan, N. 1983, "Changes in second grade children's preconceptions about the Earth as a cosmic body resulting from a short series of audio-tutorial lessons," Science Education, 67, 99

Reed, G. \& Campbell, J. R. 1972, "A comparison of the effectiveness of the planetarium and the classroom chalk board and celestial globe in the teaching of specific astronomical concepts," School Science and Mathematics, 72, 368

Schneps, M. P. 1989, A Private Universe [Video], San Francisco: Astronomical Society of the Pacific

Slater, T. F. 1993, "The effectiveness of a constructivist epistemological approach to the astronomy education of elementary and middle level in-service teachers", Unpublished doctoral dissertation, University of South Carolina, Columbia

Sneider, C. I. \& Pulos, S. 1983, "Children's cosmographies: Understanding the Earth's shape and gravity," Science Education, 67(2), 205

Stahly, L. L., Krockover, G. H. \& Shepardson, D. P. 1999, "Third grade students' ideas about the lunar phases," Journal of Research in Science Teaching, 36(2), 159

Trundle, K. C., Atwood, R. K. \& Christopher, J. E. 2002, "Preservice elementary teachers' conceptions of Moon phases before and after instruction," Journal of Research in Science Teaching, 39(7), 633

Vosniadou, S. \& Brewer, W. F. 1992, "Mental models of the Earth: A study of conceptual change in childhood," Cognitive Psychology, 24(4), 535

Zeilik, M. 1974, "A PSI astronomy course," American Journal of Physics, 42(12), 1095

Zeilik, M., Schau, C. \& Mattern, N. 1999, "Conceptual astronomy. II. Replicating conceptual gains, probing attitude changes across three semesters," American Journal of Physics, 67(10), 923

Zeilik, M., Schau, C., Mattern, N., Hall, S., Teague, K. W., \& Bisard, W. J. 1997, "Conceptual astronomy: A novel model for teaching post-secondary science courses," American Journal of Physics, 65, 987 